\title{
ANALISA PENGARUH PENAMBAHAN TULANGAN TEKAN TERHADAP DAKTILITAS KURVATUR BALOK BETON BERTULANG
}

\author{
Oscar Fithrah Nur ${ }^{1}$
}

\begin{abstract}
ABSTRAK
Salah satu usaha untuk meningkatkan kekuatan, kekakuan dan daktilitas beton bertulang dapat dilakukan dengan penambahan tulangan tekan (compression steel). Penambahan tulangan tekan pada balok beton bertulang hanya sedikit memberikan konstribusi terhadap kekuatan dan kekakuan balok, akan tetapi mempunyai pengaruh besar terhadap peningkatan daktilitas balok beton bertulang. Penyelidikan tentang model konstitutif beton (hubungan tegangan-regangan beton) tak tertekang yang dilakukan oleh Hognestad, memberikan sumbangan yang berarti dalam menganalisis perilaku daktilitas kurvatur balok beton bertulang. Berdasarkan model konstitutif beton yang diberikan oleh Hognestad tersebut, dilakukan analisis pengaruh penambahan tulangan tekan terhadap daktilitas kurvatur balok beton bertulang. Studi kasus pada penelitian ini menggunakan model benda uji dengan rasio tulangan tarik dan tulangan tekan yang bervariasi. Hasil dari analisis yang dilakukan, memperlihatkan bahwa penambahan tulangan tekan pada balok beton bertulang akan meningkatkan daktilitas kurvatur balok beton bertulang tersebut.
\end{abstract}

Kata Kunci : balok beton bertulang, penambahan tulangan tekan, model konstitutif beton, daktilitas kurvatur balok

\section{PENDAHULUAN}

\subsection{Latar Belakang}

Beton bertulang merupakan kombinasi yang baik antara beton dengan baja tulangannya. Beton mem-punyai perilaku keruntuhan getas, yaitu keruntuhan yang terjadi secara tiba-tiba jika beban yang bekerja sudah melampaui kekuatan bahan, sementara baja mempunyai perilaku keruntuhan daktail, yaitu adanya peristiwa kelelehan sebelum bahan runtuh akibat pembebanan yang diberikan. Pemberian perkuatan pada elemen balok beton bertulang, berupa penambahan tulangan tekan (compression steel) merupakan salah satu usaha untuk meningkatkan kekuatan, kekakuan dan daktilitas beton bertulang.

Penambahan tulangan tekan pada balok beton bertulang hanya sedikit memberikan konstribusi terhadap kekuatan dan kekakuan balok, akan tetapi mempunyai pengaruh besar terhadap peningkatan daktilitas kurvatur balok beton bertulang. Dengan menggunakan model konstitutif (kurva hubungan tegangan - regangan) beton bertulang tak terkekang yang diberikan oleh Hognestad dan teori daktilitas, dibuat program analisis untuk mengetahui sejauh mana pengaruh penambahan tulangan tekan terhadap daktilitas kurvatur balok beton betulang. Analisis dilakukan dengan memvariasikan rasio luas tulangan tekan pada balok beton bertulang.

\subsection{Tujuan Penelitian}

Adapun tujuan dari penelitian yang dilakukan ini adalah untuk menyelidiki pengaruh penambahan tulangan tekan terhadap daktilitas kurvatur balok beton bertulang.

\footnotetext{
${ }^{1}$ Staf Pengajar Jurusan Teknik Sipil Fakultas Teknik Universitas Andalas, e-mail: oscar@ft.unand.ac.id
} 


\section{ANALISIS PERILAKU MEKANIK BETON BERTULANG}

\subsection{Model Konstitutif Beton (Kurva Hubungan Tegangan - Regangan Beton)}

Model konstitutif beton (kurva hubungan tegangan - regangan beton) yang menggambarkan perilaku beton, biasanya diperoleh dengan menerapkan beban tekan aksial pada benda uji beton yang berbentuk selinder berukuran standar. $(\varnothing 15 \mathrm{~cm}-30 \mathrm{~cm})$. Bentuk lain dari benda uji beton, seperti kubus beton, dapat juga digunakan dengan menerapkan koefisien konversi yang sesuai. Salah satu model konstitutif beton (kurva hubungan tegangan-regangan beton) untuk beton normal yang sering digunakan dalam analisis beton bertulang adalah kurva hubungan tegangan - regangan Hognestad, seperti yang ditunjukkan oleh Gambar 1. Pendekatan yang umum digunakan pada model kurva hubungan tegangan - regangan beton sebelum mencapai tegangan maksimumnya adalah berbentuk parabola berderajat dua. Walaupun demikian, bagian awal kurva dianggap linear sampai tegangan beton lebih kurang $0,5 f_{c}^{\prime}$. Kemiringan garis lurus bagian awal kurva (pada daerah elastis), didefinisikan sebagai modulus elastisitas beton $\left(E_{c}\right)$.

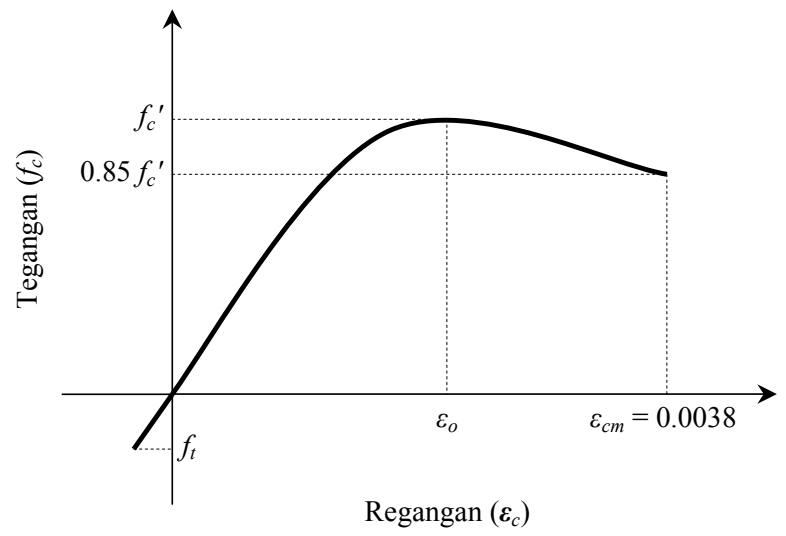

Gambar 1. Model Konstitutif Beton menurut Hognestad (Nawy, E.G., 1996)

Formulasi yang digunakan oleh Hognestad untuk mengambarkan tegangan tekan beton sebagai fungsi regangan tekan beton adalah sebagai berikut :

a. Untuk daerah $\varepsilon_{c} \leq \varepsilon_{o}$

$$
f_{c}=f_{c}^{\prime}\left[\frac{2 \varepsilon_{c}}{\varepsilon_{o}}-\left(\frac{\varepsilon_{c}}{\varepsilon_{o}}\right)^{2}\right] \mathrm{MPa} \quad ; \quad \varepsilon_{o}=\frac{2 f_{c}^{\prime}}{E_{c}}
$$

b. Untuk daerah $\varepsilon_{o} \leq \varepsilon_{c} \leq \varepsilon_{c m}$

$$
f_{c}=f_{c}^{\prime}\left[1-100\left(\varepsilon_{c}-\varepsilon_{o}\right)\right] \mathrm{MPa}
$$

Berdasarkan SNI 03-2847-2002 Tata Cara Perhitungan Struktur Beton untuk Bangunan Gedung, nilai modulus elastisitas beton $\left(E_{c}\right)$ untuk beton normal adalah :

$$
E_{c}=4700 \sqrt{f_{c}^{\prime}} \mathrm{MPa}
$$

Kekuatan beton terhadap tarik boleh dikatakan sangat kecil, akan tetapi sangat menentukan dalam perhitungan momen retak penampang. Perilaku tegangan - regangan beton dalam kondisi tarik dapat diasumsikan linear. Nilai batas kuat tarik $f_{t}$ (modulus rupture) beton, diambil berdasarkan hasil pengujian kuat tarik tak langsung (split test). Berdasarkan SNI 03-2847-2002 Tata Cara Perhitungan Struktur Beton untuk Bangunan Gedung, nilai kuat tarik $\left(f_{t}\right)$ beton normal adalah :

$$
f_{t}=0.62 \sqrt{f_{c}{ }^{\prime}} \mathrm{MPa}
$$




\subsection{Model Konstitutif Baja (Kurva Hubungan Tegangan - Regangan Baja)}

Perilaku baja tulangan dalam kondisi tarik dan kondisi tekan dapat diasumsikan sama, jika faktor tekuk pada baja diabaikan. Perilaku baja tulangan yang sebenarnya dibagi atas 4 fase, yaitu fase linear elastic (elastic linier), fase leleh (yielding), fase strain hardening dan fase weaking, seperti yang ditunjukkan pada Gambar 2 berikut.

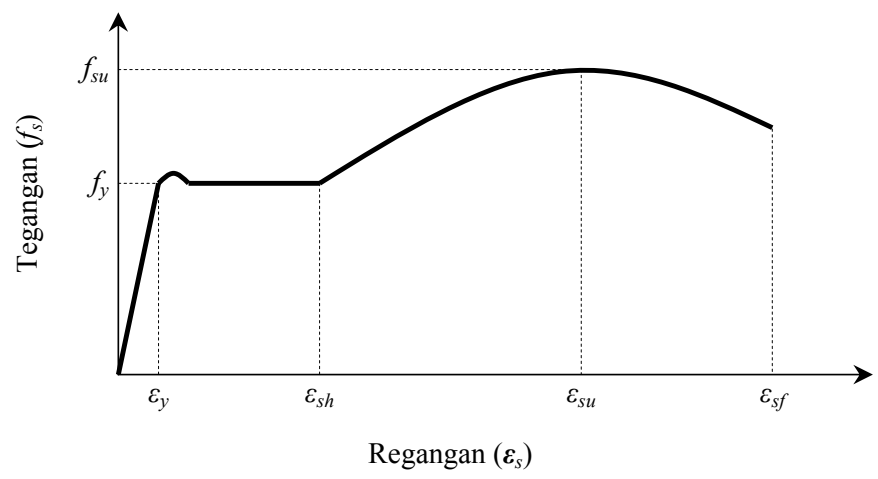

Gambar 2. Model Konstitutif Baja (Nawy, E.G., 1996)

Model konstitutif baja (kurva hubungan tegangan - regangan baja) di atas, terdapat empat daerah sebagai berikut :

a. Daerah elastis linier $\left(0 \leq \varepsilon_{s} \leq \varepsilon_{y}\right)$, dimana tegangan baja meningkat secara linear terhadap regangan baja dengan $E_{s}=200000.0 \mathrm{MPa}$.

b. Daerah elatik leleh atau yield plateu $\left(\varepsilon_{y} \leq \varepsilon_{s} \leq \varepsilon_{s h}\right)$, dimana tidak ada peningkatan tegangan atau tegangan baja $\left(f_{y}\right.$ konstan).

c. Daerah strain hardening $\left(\varepsilon_{s h} \leq \varepsilon_{s} \leq \varepsilon_{s u}\right)$, dimana tegangan meningkat secara non-linear.

d. Daerah penurunan tegangan/weaking ( $\left.\varepsilon_{s u} \leq \varepsilon_{s} \leq \varepsilon_{s f}\right)$, dimana terjadi penurunan tegangan sampai baja mengalami putus (fracture).

Menurut Park \& Paulay (1975), ada beberapa model idealisasi dari model konstitutif baja (kurva hubungan tegangan - regangan baja) yang digunakan untuk keperluan perhitungan, antara lain model kurva bilinear, model kurva trilinear dan model kurva lengkap. Pada penelitian ini, model konstitutif baja tulangan yang digunakan adalah model kurva bilinear, seperti yang ditunjukkan Gambar 3. Pada model ini, hanya terdapat 2 (dua) fase sebelum baja tulangan mengalami keruntuhan, tanpa memperhitungkan fase strain hardening. Fase pertama adalah fase linear elastik sampai mencapai regangan leleh. Fase kedua adalah fase plastis sempurna, mulai dari regangan leleh sampai mencapai regangan runtuh. Nilai regangan runtuh baja diasumsikan 0.02 .

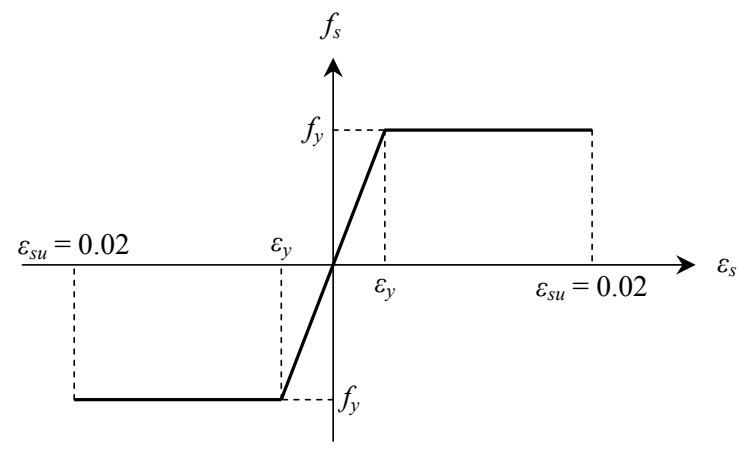

Gambar 3. Model Kurva Bilinear dari Model Konstitutif Baja (Nawy, E.G., 1996) 


\subsection{Daktilitas}

Daktilitas merupakan kemampuan struktur atau sub-struktur untuk menahan respon inelastik yang dominan dalam memikul beban agar tidak runtuh. Secara matematis, nilai daktilitas $(\mu)$ struktur didefinisikan sebagai perbandingan antara suatu parameter deformasi rencana maksimum struktur $\left(\mu_{u}\right)$ dengan deformasi pada saat terjadinya leleh pertama pada struktur yang ditinjau $\left(\mu_{y}\right)$, seperti yang diberikan dalam persamaan berikut :

$$
\mu=\frac{\Delta_{u}}{\Delta_{y}}
$$

Parameter deformasi yang umum dikenal adalah kurvatur (curvature), putaran sudut (rotational), regangan (strain) dan perpindahan (displacement).

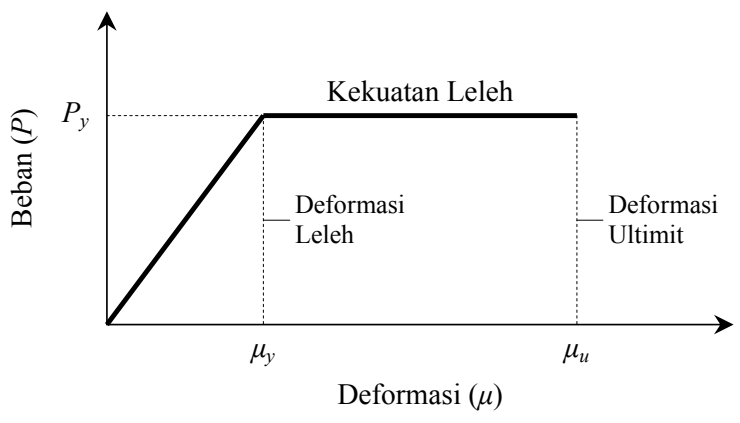

\section{Gambar 4. Definisi $\mu$ dari Daktilitas}

Macam-macam daktilitas menurut Paulay \& Priestly (1992), antara lain adalah :

a. Daktilitas regangan (strain ductility, $\mu_{\varepsilon}$ ), merupakan perbandingan regangan maksimum dengan regangan saat leleh, pada balok yang mengalami pembebanan aksial tarik atau tekan.

$$
\mu_{\varepsilon}=\frac{\varepsilon_{u, \max }}{\varepsilon_{y}}
$$

b. Daktilitas kelengkungan (curvature ductility, $\mu_{\varphi}$ ), merupakan perbandingan sudut lengkungan (angle of curvature) maksimum dengan sudut kelengkungan leleh elemen struktur akibat momen lentur.

$$
\mu_{\varphi}=\frac{\varphi_{u, \max }}{\varphi_{y}}
$$

c. Daktilitas rotasi (rotational ductility, $\mu_{\theta}$ ), merupakan perbandingan antara putaran sudut maksimum sendi plastis terhadap putaran sudut leleh.

$$
\mu_{\theta}=\frac{\theta_{u, \max }}{\theta_{y}}
$$

d. Daktilitas perpindahan (displacement ductility), merupakan perbandingan perpindahan (deformasi) maksimum struktur (arah lateral) dalam kondisi post-elastic terhadap perpindahan (deformasi) struktur saat leleh.

$$
\mu_{\delta}=\frac{\delta_{u, \max }}{\delta_{y}}
$$

\subsection{Hubungan Momen - Kurvatur Penampang}

Hubungan momen - kelengkungan (moment-curvature) suatu penampang beton bertulang yang diberi beban lentur dapat diturunkan dari persamaa keseimbangan gaya komponen penyusun 
penam-pang beton bertulang tersebut. Gaya-gaya yang terjadi pada komponen tersebut diakibatkan per-ubahan bentuk penampang sebagai reaksi dari beban luar yang bekerja pada penampang. Berdasarkan Gambar 5, dengan mengasumsikan material homogen dan berperilaku elastik linier, rotasi antara kedua ujung elemen adalah :

$$
\frac{1}{R}=\frac{\varepsilon_{c}}{k d}=\frac{\varepsilon_{s}}{d(1-k)}
$$

dimana $1 / R$ adalah kurvatur elemen (rotasi persatuan panjang elemen), dilambangkan dengan $\varphi$ :

$$
\varphi=\frac{\varepsilon_{c}}{k d}=\frac{\varepsilon_{s}}{d(1-k)}=\frac{\varepsilon_{c}+\varepsilon_{s}}{d}
$$

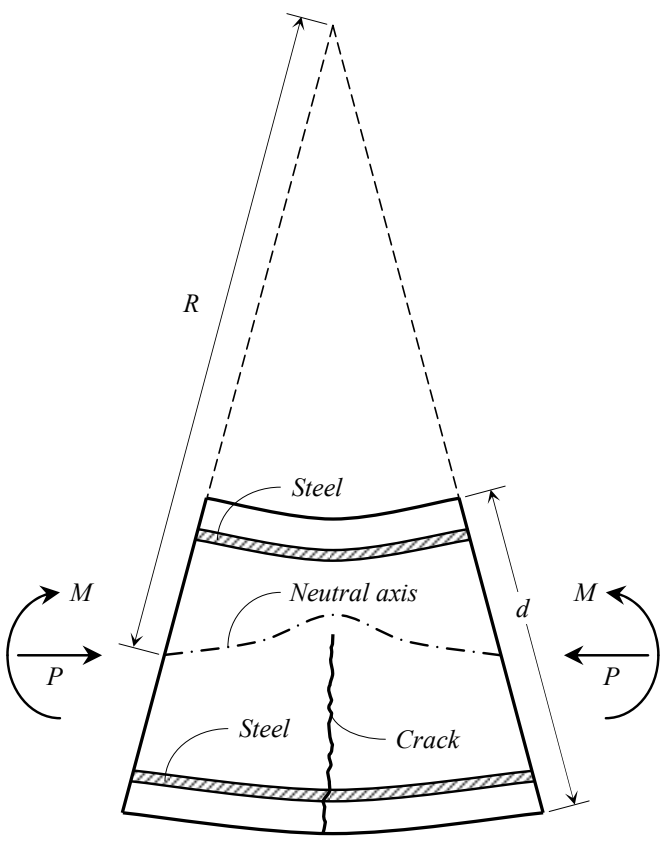

Member of Element

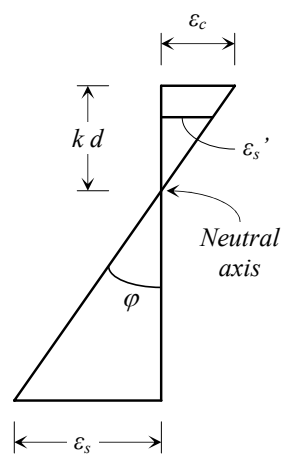

Strain Distribution

Gambar 5. Deformasi Elemen Struktur akibat Pembebanan Lentur (Park \& Paulay, 1975)
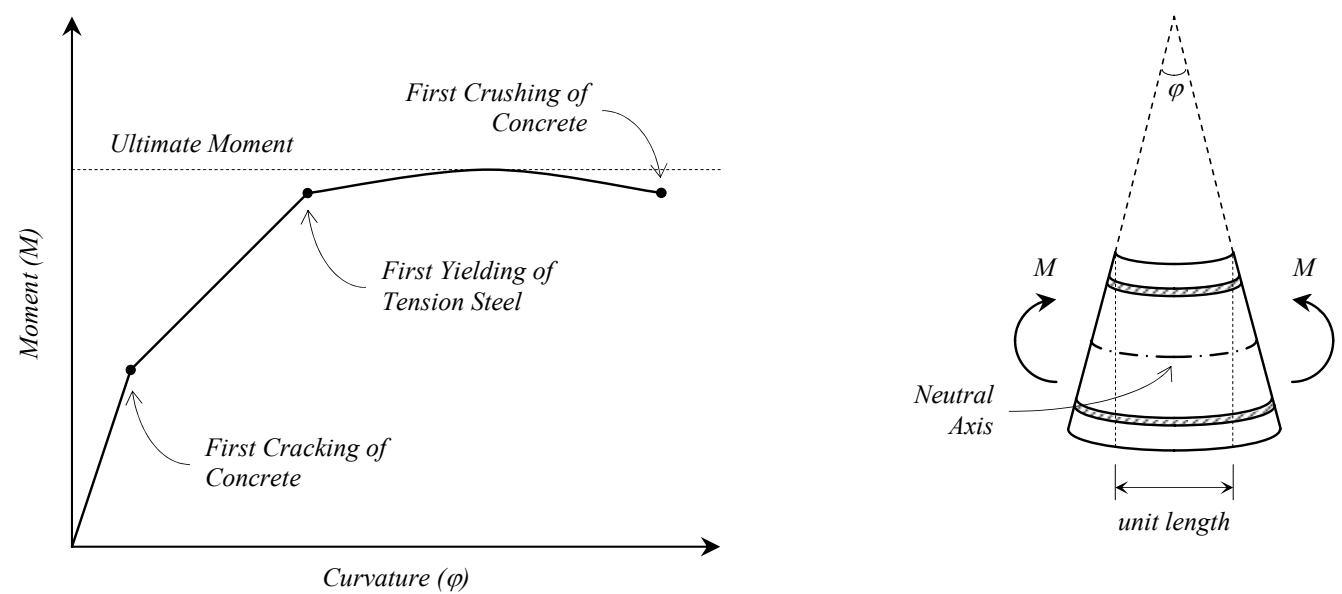

Gambar 6. Momen - Kurvatur pada Balok Beton (Park \& Paulay, 1975) 
Nilai regangan beton pada serat tekan $\left(\varepsilon_{c}\right)$ dan regangan tarik baja $\left(\varepsilon_{s}\right)$ akan bervariasi sepanjang elemen, akibat terjadinya tegangan tarik antara retak beton. Hubungan kurva momen-kelengkungan dari hasil pengukuran balok beton, yang mengambarkan tiga fase keruntuhan tarik dan tekan yang terjadi pada balok, dapat dilihat pada Gambar 6. Pada struktur elastis linier, hubungan momen lentur $(M)$ dgn parameter kelengkungan $(\varphi)$, dapat dirumuskan dengan persamaan :

$$
\varphi=\frac{M}{E I}
$$

\section{PROSEDUR PERHITUNGAN DAN ALGOTIRMA PROGRAM}

Gambar 7 memperlihatkan diagram tegangan - regangan penampang balok beton bertulang. Nilai regangan ekstrim beton bertulang $\left(\varepsilon_{c m}\right)$ didapat dengan melakukan penambahan beban dalam analisa perhitungan hingga mencapai nilai 0,0038 dengan mengasumsikan nilai kedalaman garis netral $(k d)$.

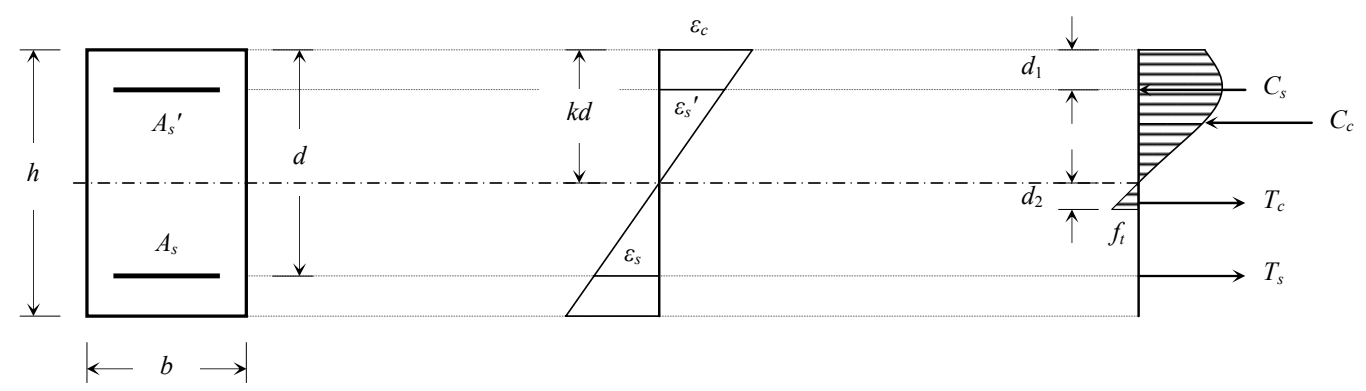

Gambar 7. Diagram Tegangan - Regangan Penampang Balok (Park \& Paulay, 1975)

\subsection{Perhitungan Gaya Dalam Komponen Beton}

Gaya tekan total komponen beton $\left(C_{c}\right)$ merupakan volume stress block parabolic, yaitu :

$$
\begin{aligned}
& C_{c}=b \int_{0}^{k d} f_{c}(\varepsilon(x)) d x \\
& \varepsilon(x)=\left(\frac{x}{k d}\right) \varepsilon_{c}
\end{aligned}
$$

dimana $x$ dihitung dari garis netral penampang.

Momen gaya tekan $\left(M C_{c}\right)$ beton terhadap tulangan tarik baja adalah :

$$
M C_{c}=b \int_{0}^{k d} f_{c} \varepsilon(x)\left(x+\left(d_{2}-k d\right)\right) d x
$$

Gaya tarik total beton $\left(T_{c}\right)$ adalah volume stress tarik block segitiga, yaitu :

$$
T_{c}=b^{1 / 2} f_{t}(h-k d)\left(\frac{f_{t}}{E_{c} \varepsilon_{s}}\right)(1-k) d
$$

Momen gaya tarik $\left(M T_{c}\right)$ beton terhadap tulangan tarik baja adalah :

$$
M T_{c}=T_{c}\left(k d+2 / 3 \frac{f_{t}}{E_{c} \varepsilon_{s}}(1-k) d-d_{2}\right)
$$




\subsection{Perhitungan Gaya Dalam Komponen Baja}

Regangan tiap baris tulangan ke- $i$ adalah :

$$
\varepsilon_{s i}=\frac{d_{i}-k d}{k d} \varepsilon_{c}
$$

Jika :

$$
\begin{array}{lll}
d_{i}-k d<0 & \rightarrow & \text { tulangan bersifat tekan } \\
d_{i}-k d>0 & \rightarrow & \text { tulangan bersifat tarik }
\end{array}
$$

Tegangan tiap baris tulangan ke- $i$ adalah :

$$
\begin{array}{lll}
f_{s i}=E_{s i} \varepsilon_{s i} & ; & f_{s i}<f_{y} \\
f_{s i}=f_{y} & ; & f_{s i}>f_{y}
\end{array}
$$

Gaya tiap baris tulangan ke- $i$ adalah :

$$
T_{s i}=A_{s i} f_{s i}
$$

Momen tulangan baris ke- $i$ ke tulangan tarik terluar :

$$
M T_{s i}=T_{s i}\left(d_{i}-d_{s}\right)
$$

Gaya total tulangan baja adalah :

$$
T_{s}=\sum_{n=1}^{n} T_{s i}
$$

Momen total tulangan ketulangan tarik terluar :

$$
M T_{s}=\sum_{n=1}^{n} M T_{s i}
$$

\subsection{Perhitungan Gaya Dalam Beton yang Diambil Komponen Baja Tulangan}

Jika ada baja tulangan yang terdapat pada daerah tekan beton, maka akan ada tegangan tekan beton yang "hilang". Kehilangan ini diwakili oleh "gaya tarik" beton yang dihitung berdasarkan regangan yang terjadi pada lokasi tulangan tersebut. Tegangan beton pada lokasi tersebut dapat dihitung berdasarkan rumusan Hognestad :

$$
F_{c i}=f_{c}\left(\varepsilon_{s i}\right)
$$

Gaya tarik beton dari tulangan ke- $i$ dapat dihitung dengan mengalikan nilai tegangan tersebut dengan luas beton yang diambil tulangan, yaitu :

$$
C T_{s i}=A_{s i} f_{c i}
$$

Momen gaya tarik beton dari tulangan baris ke-i terhadap tulangan tarik terluar adalah :

$$
M C T_{s i}=T_{s i}\left(d_{2}-d_{i}\right)
$$

Gaya tarik total beton dari tulangan adalah :

$$
C T_{c}=\sum_{n=1}^{n} C T_{c i}
$$

Momen tarik total beton dari tulangan ke tulangan tarik terluar adalah :

$$
M C T_{s}=\sum_{n=1}^{n} M C T_{c i}
$$

\subsection{Persamaan Keseimbangan Penampang}

Persamaan keseimbangan gaya normal penampang balok beton bertulang adalah :

$$
P\left(\varphi, \varepsilon_{c}\right)=T_{s}\left(\varphi, \varepsilon_{c}\right)-C c\left(\varphi, \varepsilon_{c}\right)-C T c\left(\varphi, \varepsilon_{c}\right)+T_{c}\left(\varphi, \varepsilon_{c}\right)
$$


dan persamaan momen peampang terhadap tilangan tarik terluar adalah :

$$
M\left(\varphi, \varepsilon_{c}\right)=M T_{s}\left(\varphi, \varepsilon_{c}\right)+M C c\left(\varphi, \varepsilon_{c}\right)+\operatorname{MCTc}\left(\varphi, \varepsilon_{c}\right)+M T_{c}\left(\varphi, \varepsilon_{c}\right)
$$

\subsection{Perhitungan Momen - Kurvatur Penampang}

Penentuan nilai kurvatur $\varphi$ agar diperoleh nilai $P\left(\varphi, \varepsilon_{c}\right)=0$ untuk nilai $\varepsilon_{c}$ yang konstan, dilakukan dengan Metoda Iterasi Bisection. Nilai batas iterasi untuk $\varepsilon_{s}$ adalah $\varepsilon_{s}=-0.02$ (batas bawah, regangan putus baja) dan $\varepsilon_{s}=\varepsilon_{c}$ (batas atas, diambil sama regangan tekan beton). Pada batas bawah, dipastikan gaya normal penampang adalah tarik dan pada batas atas, dipastikan gaya normal penampang adalah tekan. Diantara dua nilai tersebut pasti terdapat nilai $P\left(\varphi, \varepsilon_{c}\right)=0$. Setelah kondisi keseimbangan tercapai, kurvatur penampang dapat dihitung dengan rumusan :

$$
\varphi=\frac{\varepsilon_{c m}}{k d}
$$

Nilai kurvatur $\varphi$ yang diperoleh, dimasukkan dalam Pers. 31. untuk mendapatkan nilai momen lentur murni. Proses dimulai dari $\varepsilon_{c}=0.0001$, dengan pertambahan regangan sebesar 0.0001 sampai beton hancur $\left(\varepsilon_{c}=\varepsilon_{c m}=0.0038\right)$. Jika pada salah satu iterasi ditemukan kondisi non-konvergen, dipastikan hal tersebut diakibatkan solusi $\varepsilon_{s}$ sudah melewati nilai 0.02 (regangan putus tulangan baja), sehingga perhitungan harus dihentikan. Momen dan kurvatur terakhir diperoleh adalah dalam kondisi ultimit, ditentukan dengan keruntuhan tulangan tarik baja. Jika tidak ditemukan kenonkonvergenan sampai regangan beton mencapi nilai $\varepsilon_{c m}=0.0038$, maka diperoleh momen dan kurvatur dalam kondisi ultimit yang ditandai dengan keruntuhan tekan beton.

\subsection{Perhitungan Momen - Kurvatur Retak dan Leleh}

Nilai momen dan kurvatur balok pada kondisi retak pertama, diperoleh dengan persamaan :

$$
\varphi_{c r}=\frac{M}{E I_{e k}} \quad ; \quad M_{c r}=f_{t} W_{e k}
$$

Pada kondidi leleh pertama, program dapat dimodifikasi dengan mengambil parameter $\varepsilon_{s}$ sebagai parameter konstan sebesar $\varepsilon_{s}=\varepsilon_{y}$ dan $\varepsilon_{c}$ divariasikan untuk mendapatkan $\varphi_{y}$ yang memberikan $P\left(\varphi, \varepsilon_{c}\right)=0$. Momen lentur yang terjadi merupakan momen leleh $M_{y}=M\left(\varphi_{y}, \varepsilon_{c}\right)$.

\subsection{Bagan Alir (Flowchart)}
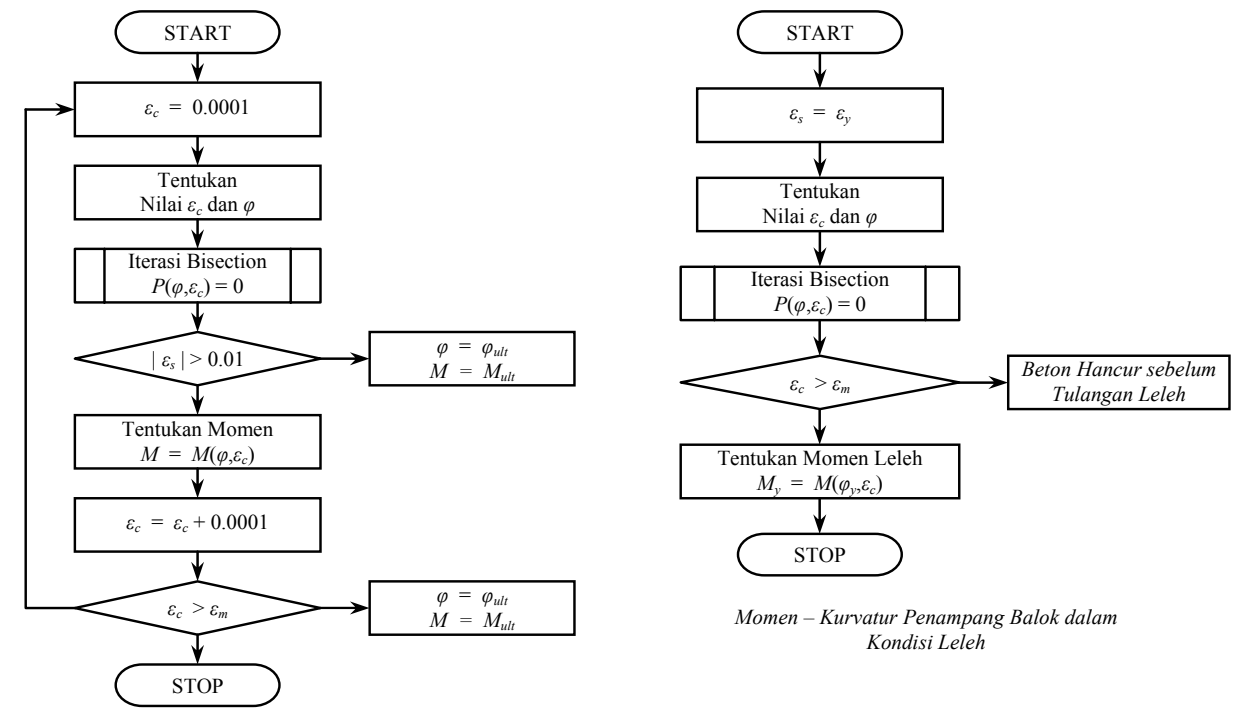

Gambar 8. Bagan Alir Perhitungan 


\section{STUDI KASUS DAN ANALISA}

Data-data penampang balok beton bertulang yang akan dianalisis pada penelitian ini adalah sebagai berikut :

a. Data Penampang

- Lebar balok : $b=300.0 \mathrm{~mm}$

- Tinggi Balok : $h=600.0 \mathrm{~mm}$

- Selimut Beton : $d^{\prime}=50.0 \mathrm{~mm}$

$d=550.0 \mathrm{~mm}$

b. Data Beton

- Kuat tekan beton $\quad: f_{c}{ }^{\prime}=30.0 \mathrm{MPa}$

- Regangan runtuh : $\varepsilon_{c m}=0.0038$

- Modulus elastisitas : $E_{c}=4700 \sqrt{f_{c}{ }^{\prime}}=25742.96 \mathrm{MPa}$

- Kuat tarik beton $\quad: f_{t}=0.62 \sqrt{f_{c}{ }^{\prime}}=3.3959 \mathrm{MPa}$

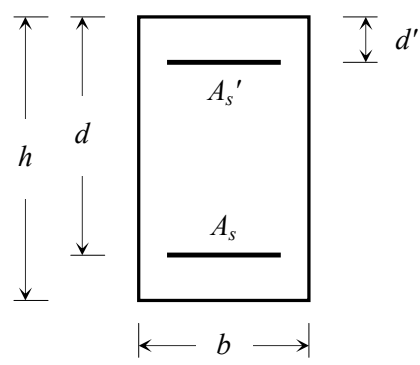

c. Data Baja Tulangan

- Tegangan leleh baja : $f_{s}=320.0 \mathrm{MPa}$

- Modulus elastisitas : $E_{s}=200000.0 \mathrm{MPa}$

- Regangan putus $\quad: \varepsilon_{s m}=0.02$

Penelitian ini dilakukan dengan menggunakan 20 model balok beton bertulang rangkap dengan memvariasikan luas tulangan tarik dan luas tulangan tekan $\left(\rho^{\prime} / \rho\right)$, seperti yang dapat dilihat pada Tabel 1 di bawah ini.

Tabel 1. Variasi Luas Tulangan Tekan dan Tarik pada Penampang Balok Beton Bertulang

\begin{tabular}{|c|c|c|c|c|c|c|c|c|c|c|c|}
\hline $\begin{array}{c}\text { Tipe } \\
\text { Balok }\end{array}$ & $\rho$ & $\rho^{\prime}$ & $\begin{array}{c}A_{s}=\rho b d \\
\left(\mathrm{~mm}^{2}\right)\end{array}$ & $\begin{array}{c}A_{s}{ }^{\prime}=\rho^{\prime} b d \\
\left(\mathrm{~mm}^{2}\right)\end{array}$ & $\rho^{\prime} / \rho$ & $\begin{array}{c}\text { Tipe } \\
\text { Balok }\end{array}$ & $\rho$ & $\rho^{\prime}$ & $\begin{array}{c}A_{s}=\rho b d \\
\left(\mathrm{~mm}^{2}\right)\end{array}$ & $\begin{array}{c}A_{s}^{\prime}=\rho^{\prime} b d \\
\left(\mathrm{~mm}^{2}\right)\end{array}$ & $\rho^{\prime} / \rho$ \\
\hline R1-1 & 0.0375 & 0.0375 & 6187.500 & 6187.500 & 1.0000 & R3-1 & 0.0125 & 0.0125 & 2062.500 & 2062.500 & 1.0000 \\
\hline R1-2 & 0.0375 & 0.0281 & 6187.500 & 4640.625 & 0.7500 & R3-2 & 0.0125 & 0.0094 & 2062.500 & 1546.875 & 0.7500 \\
\hline R1-3 & 0.0375 & 0.0187 & 6187.500 & 3093.750 & 0.5000 & R3-3 & 0.0125 & 0.0063 & 2062.500 & 1031.250 & 0.5000 \\
\hline R1-4 & 0.0375 & 0.0094 & 6187.500 & 1546.875 & 0.2500 & R3-4 & 0.0125 & 0.0031 & 2062.500 & 515.625 & 0.2500 \\
\hline R1-5 & 0.0375 & 0.0000 & 6187.500 & 0.000 & 0.0000 & R3-5 & 0.0125 & 0.0000 & 2062.500 & 0.000 & 0.0000 \\
\hline R2-1 & 0.0250 & 0.0250 & 4125.000 & 4125.000 & 1.0000 & R4-1 & 0.00625 & 0.00625 & 1031.2500 & 1031.2500 & 1.0000 \\
\hline R2-2 & 0.0250 & 0.0188 & 4125.000 & 3093.750 & 0.7500 & R4-2 & 0.00625 & 0.00469 & 1031.2500 & 773.4375 & 0.7500 \\
\hline R2-3 & 0.0250 & 0.0125 & 4125.000 & 2062.500 & 0.5000 & R4-3 & 0.00625 & 0.00313 & 1031.2500 & 515.6250 & 0.5000 \\
\hline R2-4 & 0.0250 & 0.0063 & 4125.000 & 1031.250 & 0.2500 & R4-4 & 0.00625 & 0.00156 & 1031.2500 & 257.8125 & 0.2500 \\
\hline R2-5 & 0.0250 & 0.0000 & 4125.000 & 0.000 & 0.0000 & R4-5 & 0.00625 & 0.00000 & 1031.2500 & 0.0000 & 0.0000 \\
\hline
\end{tabular}

\subsection{Analisis Pengaruh Penambahan Tulangan Tekan terhadap Momen - Kurvatur}

Kurva hubungan momen - kurvatur penampang yang diperoleh dari hasil keluaran program untuk masing-masing tipe penampang balok beton bertulang, dapat dilihat pada Gambar 9.

Bentuk kurva hubungan momen - kurvatur yang diperoleh, secara umum terbagi atas tiga fase, yaitu : (1) fase sebelum retak, (2) fase antara retak pertama dengan leleh pertama dan (3) fase antara leleh pertama dengan runtuh. 


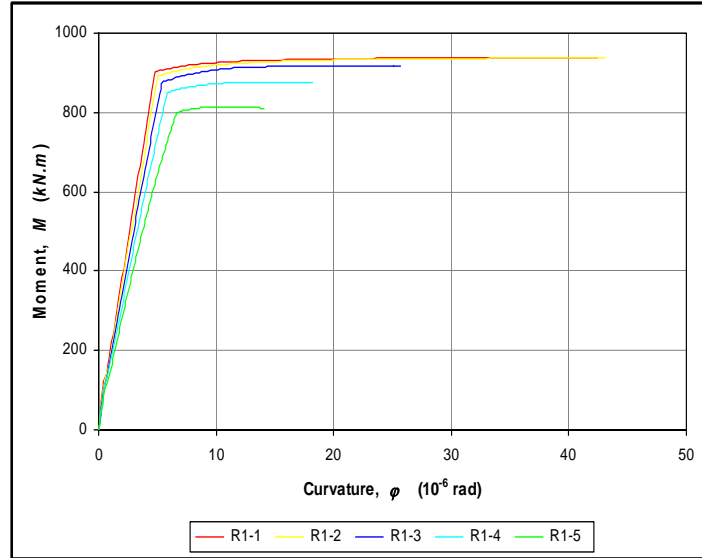

Balok R1 $\left(A_{s}=6187.50 \mathrm{~mm}^{2}\right)$

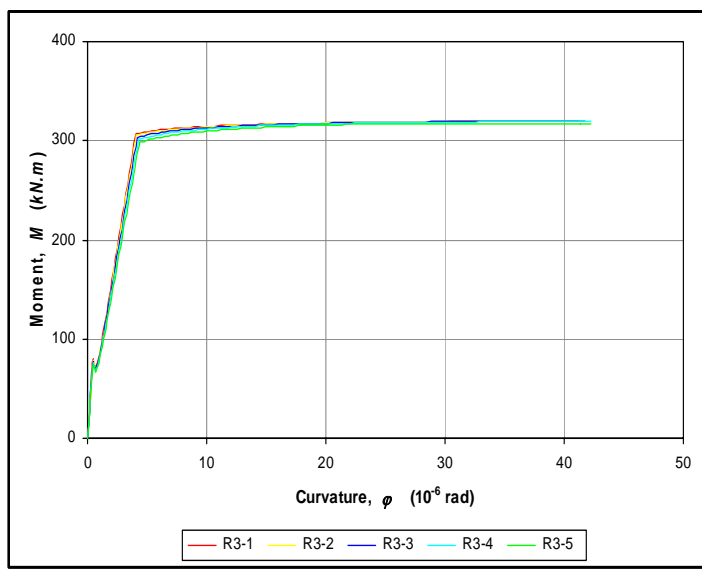

Balok R3 $\left(A_{s}=2062.50 \mathrm{~mm}^{2}\right)$

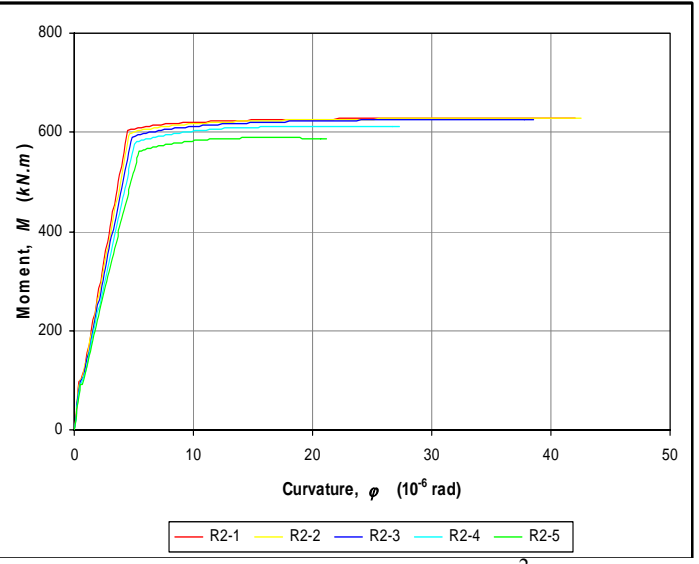

Balok R2 $\left(A_{s}=4125.00 \mathrm{~mm}^{2}\right)$

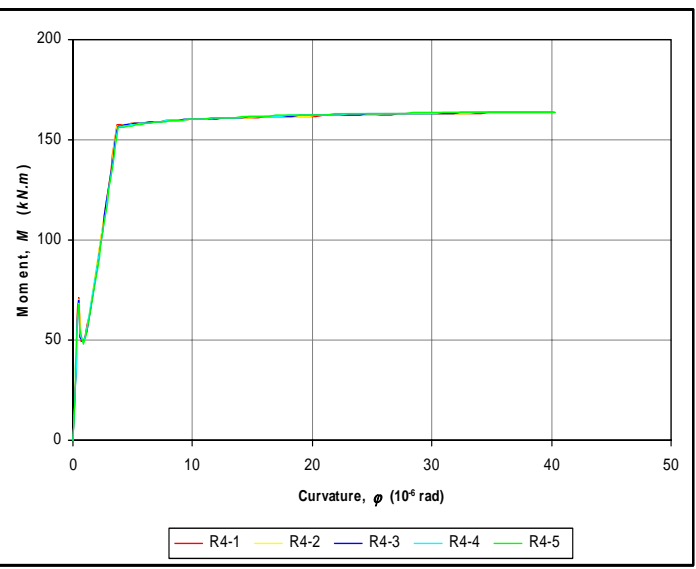

Balok R4 $\left(A_{s}=1031.25 \mathrm{~mm}^{2}\right)$

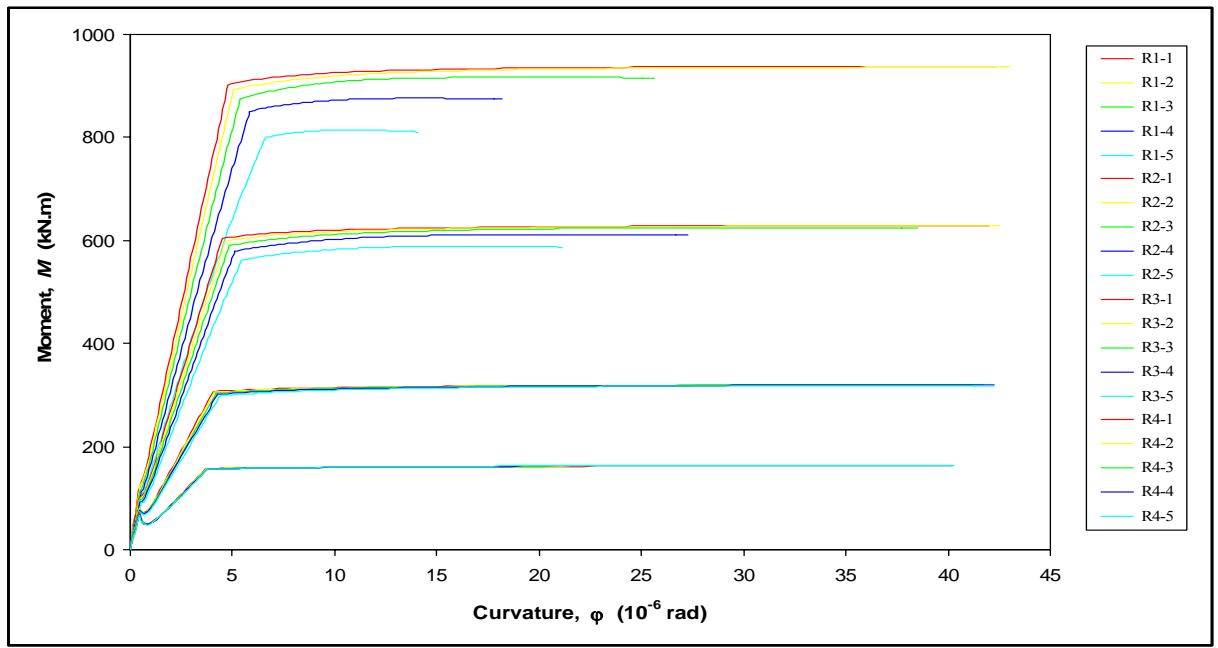

Gambar 9. Kurva Momen - Kurvatur pada Balok Beton Bertulang

Pada kedua fase pertama, kenaikan nilai kurvatur penampang $(\varphi)$ selalu diiringi dengan kenaikan nilai momen $(M)$. Pada fase ketiga, kenaikan nilai kurvatur penampang tidak selalu diiringi dengan kenaikan momen (momen yang dihasilkan cendrung konstan). Pada fase ketiga, terdapat dua 
perilaku kenaikan momen yang berbeda pada penampang balok. Yang pertama adalah nilai momen yang selalu naik sampai penampang mengalami keruntuhan dan yang kedua adalah nilai momen yang naik terlebih dahulu kemudian turun sampai penampang mengalami keruntuhan.

\subsection{Analisis Pengaruh Penambahan Tulangan Tekan terhadap Daktilias Kurvatur}

Daktilitas kurvatur merupakan perbandingan antara nilai kurvatur panampang pada kondisi ultimit dengan nilai kurvatur penampang pada kondisi leleh. Nilai-nilai daktilitas kurvatur penampang dapat dilihat pada Tabel 2. Sedangkan kurva hubungan daktilitas kurvatur dengan rasio luas tulangan baja, untuk masing-masing tipe balok dan untuk masing-masing rasio tulangan tekan dengan tulangan tarik, ditunjukkan pada Gambar 10 dan Gambar 11.

Tabel 2. Daktilitas Kurvatur Penampang Balok Beton Bertulang

\begin{tabular}{|c|c|c|c|c|c|c|c|c|r|}
\hline $\begin{array}{c}\text { Tipe } \\
\text { Balok }\end{array}$ & $\boldsymbol{\rho}$ & $\boldsymbol{\rho}^{\prime}$ & $\boldsymbol{\rho}^{\prime} / \boldsymbol{\rho}$ & $\begin{array}{c}\text { Daktilitas } \\
\text { Kurvatur }\end{array}$ & $\begin{array}{c}\text { Tipe } \\
\text { Balok }\end{array}$ & $\boldsymbol{\rho}$ & $\boldsymbol{\rho}^{\prime}$ & $\boldsymbol{\rho}^{\prime} / \boldsymbol{\rho}$ & $\begin{array}{c}\text { Daktilitas } \\
\text { Kurvatur }\end{array}$ \\
\hline R1-1 & 0.0375 & 0.0375 & 1.0000 & $\mathbf{8 . 8 3 3 4}$ & $\mathbf{R 3 - 1}$ & 0.0125 & 0.0125 & 1.0000 & $\mathbf{1 0 . 1 9 4 8}$ \\
\hline R1-2 & 0.0375 & 0.0281 & 0.7500 & $\mathbf{8 . 5 3 8 6}$ & $\mathbf{R 3 - 2}$ & 0.0125 & 0.0094 & 0.7500 & $\mathbf{1 0 . 0 7 4 5}$ \\
\hline R1-3 & 0.0375 & 0.0188 & 0.5000 & $\mathbf{4 . 7 7 5 1}$ & $\mathbf{R 3 - 3}$ & 0.0125 & 0.0063 & 0.5000 & $\mathbf{9 . 9 6 1 7}$ \\
\hline R1-4 & 0.0375 & 0.0094 & 0.2500 & $\mathbf{3 . 1 1 4 8}$ & $\mathbf{R 3 - 4}$ & 0.0125 & 0.0031 & 0.2500 & $\mathbf{9 . 8 7 9 3}$ \\
\hline R1-5 & 0.0375 & 0.0000 & 0.0000 & $\mathbf{2 . 1 2 0 1}$ & $\mathbf{R 3 - 5}$ & 0.0125 & 0.0000 & 0.0000 & $\mathbf{9 . 6 4 7 2}$ \\
\hline R2-1 & 0.0250 & 0.0250 & 1.0000 & $\mathbf{9 . 3 3 9 4}$ & $\mathbf{R 4 - 1}$ & 0.0063 & 0.0063 & 1.0000 & $\mathbf{1 0 . 9 1 9 9}$ \\
\hline R2-2 & 0.0250 & 0.0188 & 0.7500 & $\mathbf{9 . 1 2 3 2}$ & $\mathbf{R 4 - 2}$ & 0.0063 & 0.0047 & 0.7500 & $\mathbf{1 0 . 8 4 1 8}$ \\
\hline R2-3 & 0.0250 & 0.0125 & 0.5000 & $\mathbf{7 . 9 3 8 4}$ & $\mathbf{R 4 - 3}$ & 0.0063 & 0.0031 & 0.5000 & $\mathbf{1 0 . 7 6 0 4}$ \\
\hline R2-4 & 0.0250 & 0.0063 & 0.2500 & $\mathbf{5 . 3 3 7 1}$ & $\mathbf{R 4 - 4}$ & 0.0063 & 0.0016 & 0.2500 & $\mathbf{1 0 . 6 7 6 0}$ \\
\hline R2-5 & 0.0250 & 0.0000 & 0.0000 & $\mathbf{3 . 8 7 5 5}$ & $\mathbf{R 4 - 5}$ & 0.0063 & 0.0000 & 0.0000 & $\mathbf{1 0 . 5 8 9 7}$ \\
\hline
\end{tabular}

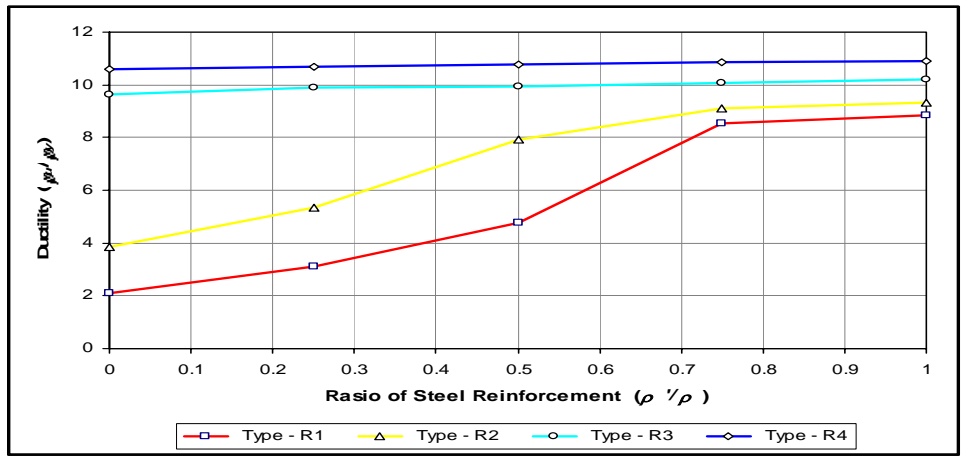

Gambar 10. Daktilitas Kurvatur - Rasio Luas Tulangan Baja berdasarkan Tipe Balok

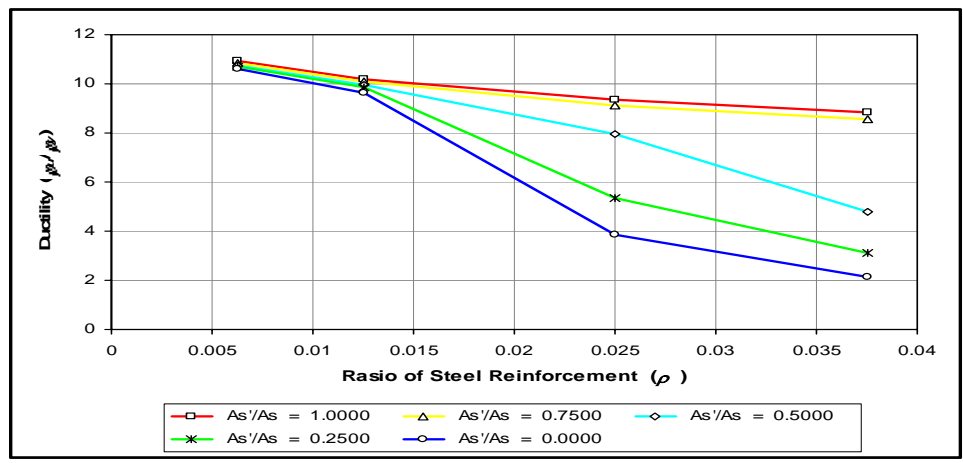

Gambar 11. Daktilitas Kurvatur - Rasio Luas Tulangan Baja berdasarkan Luas Tulangan 
Penambahan tulangan tekan pada balok, tidak terlalu banyak memberikan sumbangan kekuatan pada balok, akan tetapi sangat membantu dalam meningkatkan daktilitas kurvatur penampang. Hal ini disebabkan karena adanya peningkatan kekuatan pada daerah tekan penampang balok, mengakibatkan tulangan baja pada daerah tarik akan dipaksa untuk meleleh lebih cepat.

Untuk penampang balok yang mempunyai luas tulangan tarik lebih sedikit, cendrung mempunyai nilai daktilitas kurvatur yang besar, akan tetapi kekuatannya lebih rendah. Hal ini disebabkan karena adanya perlemahan pada daerah tarik penampang, yang mengakibatkan tulangan baja pada daerah tarik dipaksa untuk meleleh lebih cepat.

\section{KESIMPULAN}

Bedasarkan hasil analisis yang telah dilakukan, dapat diambil kesimpulan sebagai berikut :

1. Secara umum, kurva hubungan momen-kurvatur penampang balok beton bertulang terbagi atas 3 (tiga) fase, yaitu fase sebelum retak, fase antara retak pertama dengan leleh pertama dan fase antara leleh pertama dengan runtuh.

2. Penambahan tulangan tekan pada balok beton bertulang, tidak banyak memberikan konstribusi terhadap peningkatan kekuatan balok, akan tetapi sangat membantu dalam meningkatkan daktilitas kurvatur penampang. Hal ini disebabkan karena adanya peningkatan kekuatan pada daerah tekan penampang balok, mengakibatkan tulangan baja pada daerah tarik akan dipaksa untuk meleleh lebih cepat. Selain itu, dengan penambahan tulangan tekan akan juga menyebabkan kedalaman garis netral menjadi kecil, yang mengakibatkan kurvatur penampang menjadi lebih besar.

3. Penampang balok beton bertulang yang mempunyai luas tulangan tarik lebih sedikit, cendrung mempunyai nilai daktilitas kurvatur yang besar, akan tetapi kekuatannya lebih rendah. Hal ini disebabkan karena adanya perlemahan pada daerah tarik penampang, mengakibatkan tulangan baja pada daerah tarik dipaksa untuk meleleh lebih cepat.

\section{DAFTAR PUSTAKA}

Nawy, E.G., (1996), "Reinforced Concrete, Fundamental Approach", $3^{\text {rd }}$ ed, Prentice-Hall Inc., New York.

Kong, F.K., Evans, R.H., Cohen, (1983), "Handbook of Structural Concrete", Mc Graw Hill Book Company, New York.

Park, R., Paulay, T., (1975), "Reinforced Concrete Structure", John Wiley \& Sons, New York.

Paulay, T., Priestley, M.J.N., (1992), "Seismic Design of Reinforce Concrete and Masonry Buildings", John Willey \& Sons, New York. 